\title{
Variation of flatband potential of oxide nanocrystalline particles with core-shell structured semiconductor-MgO composites
}

\author{
J. Bandara* and U. W. Pradeep
}

Institute of Fundamental Studies, Hantana Road, Kandy.

\begin{abstract}
$\mathrm{SnO}_{2}$ thin films and particles show feeble solar cell performance and poor photocatalytic activity respectively. It has been reported that coating of a thin $\mathrm{MgO}$ layer on $\mathrm{SnO}_{2}$ particles results in enhancement of both solar cell performance and catalytic activities. The promoting effect of $\mathrm{MgO}$ layer was owing to barrier effect where $\mathrm{MgO}$ acts as a barrier layer for charge recombination. We noticed negative shift of flatband (FB) potential of $\mathrm{SnO}_{2}$ with the increase of $\mathrm{pH}$ values and coating of a thin $\mathrm{MgO}$ layer on $\mathrm{SnO}_{2}$ particles. It is shown how the negative shift in $\mathrm{FB}$ potential may contribute to enhance the solar cell efficiencies and photocatalytic activity in addition to the barrier effect of MgO layer.
\end{abstract}

\section{INTRODUCTION}

The primary process of any photochemical reaction is the absorption of light by a suitable light absorbing material i.e. a semiconductor or dye. The direct band gap excitation of semiconductors leads to the generation of electron hole pairs and the use of semiconductor oxide particles as photocatalysts is well established and has shown great utility in the complete mineralization of organic pollutants [1-5]. In the same way, in dye sensitized solar cells (DSSC), dye molecules which are attached to thin oxide film transfer excited electrons from the dye molecules to the conduction band (CB) of the oxide. Transferred electrons in the $\mathrm{CB}$ of oxide thin film are either diffused to the conducting glass or recombine with the dye cation. In photocatalysis and in DSSC, the kinetics of recombination process is considered as one of the most important factors that controls the photocatalytic activity as well as the efficiency of solar cells [6-9]. Therefore, in optimization of the photoelectrochemical processes, recombination should be minimized. Hence, a wide charge

* Corresponding author, e-mail: jayasundera@yahoo.com 
separation is a prerequisite for better photocatalytic activity as well as higher solar cell performances. Wider charge separation has been achieved using composite semiconducting materials with different band positions such as $\mathrm{TiO}_{2} / \mathrm{SnO}_{2}[10], \mathrm{TiO}_{2} / \mathrm{ZnO}$ [11]. It has been reported about the use of an insulating layer on thin semiconducting films to increase the solar cell efficiencies and photocatalytic activities [12-16]. An interrelation between retardation of charge recombination in the presence of an insulting layer and the enhancement of the cell efficiencies and photocatalytic activities has been observed. We noticed negative shift of flatband (FB) potentials of oxide thin films with the introduction of thin MgO layer on oxide particles. Here we report how the flatband potential of oxide nanocrystalline particles vary with the core-shell oxide-MgO composite and its impact on performance of DSSC.

\section{EXPERIMENTAL}

For electrochemical measurements, thin films of nanocrystalline $\mathrm{SnO}_{2}$ and $\mathrm{SnO}_{2} / \mathrm{MgO}$ were prepared by mixing $\mathrm{SnO}_{2}$ or $\mathrm{SnO}_{2} / \mathrm{MgO}$ in an agate motar adding few drops of carbowax and polyethylene glycol. The final slurry was applied on a cleaned conducting glass by using doctor blade method and sintered in air at $450^{\circ} \mathrm{C}$ for $30 \mathrm{~min}$. The flat-band (FB) potentials of the oxides were determined from Mott-Schottky plots (i.e a plot of $\mathrm{C}^{-2} \mathrm{vs} \mathrm{V}$, where $\mathrm{C}$ was the capacitance and V was the potential across the space charge layer) and on-set potential methods. The experimental details are given in [17-19]. To measure the capacitance, oxide coated plates were immersed in $\mathrm{Na}_{2} \mathrm{SO}_{4}$ solution and the capacitances were measured as a function of the potential across the space charge layer at frequencies of $500 \mathrm{~Hz}$ and $1 \mathrm{kHz}$. It should be noted that even though both methods give comparable FB potential values, the deviations in measured FB potential values among the same and different measurement techniques were observed.

\section{RESULTS AND DISCUSSION}

It has been shown that an oxide like $\mathrm{TiO}_{2}$ follows Nernest equation and flatband potential depends on $\mathrm{pH}$ with the slope of $-59 \mathrm{mV} / \mathrm{pH}$ and the dependence of flatband on $\mathrm{pH}$ was elucidated considering the following dissolution equilibrium at the $\mathrm{TiO}_{2}$ surface [19],

$$
\begin{aligned}
& \mathrm{Ti}-\mathrm{O}^{2-}+\mathrm{H}^{+} \longrightarrow \mathrm{Ti}-\mathrm{OH}^{-} \\
& \mathrm{Ti}-\mathrm{O}^{2-}=\mathrm{TiO}_{2} \text { lattice at the surface, } \mathrm{Ti}-\mathrm{OH}^{-}=\text {protonated lattice }
\end{aligned}
$$


A thermodynamic reasoning leads to the following formula for the shift in the equilibrium potential $(\Delta \theta)$ of the $\mathrm{TiO}_{2}$

$$
\Delta \theta=\text { constant }+\left(\frac{\mathrm{RT}}{\mathrm{F}}\right) \ln \left(\frac{\mathrm{a}_{\left(\mathrm{Ti}-0^{2-}\right)}}{\mathrm{a}_{\left(\mathrm{Ti}-\mathrm{OH}^{-}\right)}}\right)-\frac{2.3 \mathrm{RT}}{\mathrm{F}} \mathrm{pH}
$$

For $\mathrm{TiO}_{2}$, $\mathrm{pH}$ dependence of the second term is negligible. A change in $\mathrm{pH}$ by a unit produces a change in the potential difference within the Helmholtz layer of $2.3 R T / F$ or $59 \mathrm{mV}$ at room temperature. Fig. 1 shows the flatband variation of $\mathrm{SnO}_{2}$ particles as a function of the solution $\mathrm{pH}$ value. Similar to $\mathrm{TiO}_{2}$, the flatband potential of $\mathrm{SnO}_{2}$ decreases or shifts negatively as the solution $\mathrm{pH}$ increases. However, according to Fig. 1, the flatband potential of $\mathrm{SnO}_{2}$ particles varies linearity on $\mathrm{pH}$ with a slope of $-29 \mathrm{mV} / \mathrm{pH}$. i.e It has flatband potential of $0.02 \mathrm{eV}$ at $\mathrm{pH} 0.0$ and it decreases to $-0.28 \mathrm{eV}$ at $\mathrm{pH}$ 10.0. The deviation of the dependence of $\theta$ of $\mathrm{SnO}_{2}$ with solution $\mathrm{pH}$ indicates that entire surface of $\mathrm{SnO}_{2}$ lattice does not protonated instead it undergoes passivation with the increase in solution $\mathrm{pH}$.

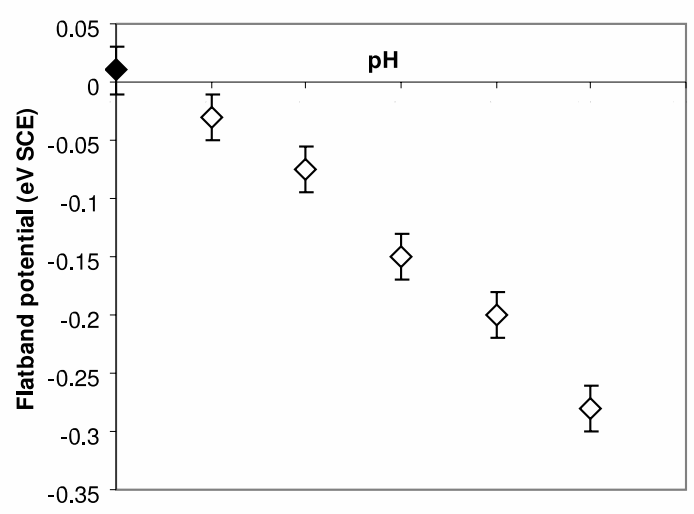

Fig. 1 Variation of flatband potential for $\mathrm{SnO}_{2}$ as a function of solution $\mathrm{pH}$.

Fig. 2 shows the flatband values for the $\mathrm{SnO}_{2} / \mathrm{MgO}$ composite with the variation of $\mathrm{MgO}$ amounts at $\mathrm{pH}$ 5.0. As shown in Fig. 2, pure $\mathrm{SnO}_{2}$ has a flatband potential of - $0.07 \mathrm{eV}$ at $\mathrm{pH} 5.0$ (vs SCE). Introduction of $1 \% \mathrm{MgO}$ results in shift in flatband potential of $\mathrm{SnO}_{2}$ to $-0.43 \mathrm{eV}$ and further increase in $\mathrm{MgO}$ leads to the negative shift in flatband potential. The flatband potential of $\mathrm{SnO}_{2}$ is at optimum when the $\mathrm{MgO}$ amount was found to be $10 \%$ and corresponding flatband potential of $\mathrm{SnO}_{2}$ particles at the optimum $\mathrm{MgO}$ was found to be $-0.84 \mathrm{eV}$. From the flatband values, it can be assumed that coating of $\mathrm{MgO}$ layer on $\mathrm{SnO}_{2}$ particles leads to some sort of surface or structural modification in $\mathrm{SnO}_{2}$ particles resulting a negative shift of flatband potential. The effect of $\mathrm{MgO}$ coating on negative shift in $\mathrm{FB}$ of $\mathrm{SnO}_{2}$ can be understood considering the acidity and basicity of 
$\mathrm{SnO}_{2}$ and $\mathrm{MgO} . \mathrm{SnO}_{2}$ is acidic because of its point of zero charge (PZC) is 4.5 while $\mathrm{MgO}$ is basic and its $\mathrm{PZC}$ is 12.0 which is supposed to be the highest basic oxide. In $\mathrm{SnO}_{2}$-MgO core-shell structure, there is a tendency of deprotonation of $\mathrm{SnO}_{2}$ surface by basic $\mathrm{MgO}$ similar to acid base deprotonation/protonation in solutions. Recently Jung et.al have investigated the $\mathrm{TiO}_{2}-\mathrm{MgO}$ core shell structure and demonstrated that $\mathrm{TiO}_{2}-\mathrm{MgO}$ core-shell structure possessed a large number of hydroxyl groups [20]. Deprotonation of $\mathrm{SnO}_{2}$ surface by basic $\mathrm{MgO}$ could lead to negative shift in $\mathrm{FB}$ of $\mathrm{SnO}_{2}$ as described above for the $\mathrm{TiO}_{2}$ particles.

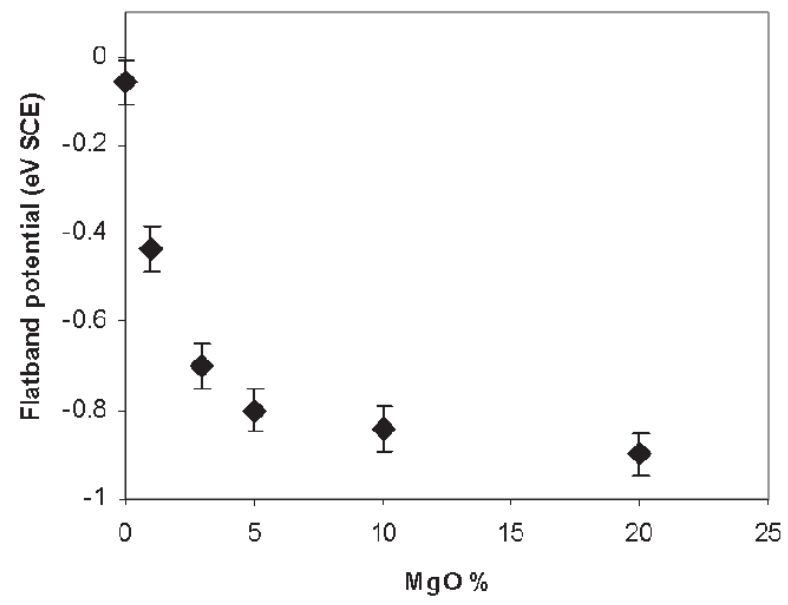

Fig. 2 Variation of flatband potential for $\mathrm{SnO}_{2}$ with the change of \% of $\mathrm{MgO}$ at $\mathrm{pH}$ 5.0.

The negative shift of $\mathrm{FB}$ of $\mathrm{SnO}_{2}$ with the change of $\mathrm{pH}$ and coating of a thin $\mathrm{MgO}$ layer could lead to enhance the performance of DSSC as well as photocatalytic activity. As described in the introduction and mentioned in literature, the performance of DSSC strongly depends not only on efficiency of charge transfer from the excited dye molecules to the $\mathrm{CB}$ of oxide but also on charge recombination kinetics between transferred electrons in the CB and the oxidized dye cation. In thermodynamic point of view, the negative shift in FB potential results in decrease in free energy change for the charge transfer from excited molecules to the CB while increase in free energy change was expected for the charge recombination process. Consequently, the negative shift in FB will facilitate the charge transfer from excited dye molecules to the $\mathrm{CB}$ while charge recombination process will be more difficult and such a situation favourably increases the efficiency of DSSC.

\section{CONCLUSION}

The FB potential of $\mathrm{SnO}_{2}$ varies linearly with the increase in solution $\mathrm{pH}$ with a slope of $-29 \mathrm{mV} / \mathrm{pH}$. The passivation of $\mathrm{SnO}_{2}$ surface may result in deviation from the Nernstein behavior. Negative shift of $\mathrm{FB}$ of $\mathrm{SnO}_{2}$ was also observed with the introduction of a thin insulating $\mathrm{MgO}$ layer on $\mathrm{SnO}_{2}$ particles and the $\mathrm{FB}$ of $\mathrm{SnO}_{2}$ is at optimum when the $\mathrm{MgO}$ amount was found to be $10 \%$. 
Deprotonation of $\mathrm{SnO}_{2}$ surface by $\mathrm{MgO}$ was found to be the reason for the observed negative shift of FB of core-shell structured $\mathrm{SnO}_{2} / \mathrm{MgO}$ composite. Negative shift in FB potential may contribute to enhance the solar cell efficiencies and photocatalytic activity in addition to the barrier effect of MgO layer.

\section{REFERENCES}

1. D. F. Ollis, H. Al-Ekabi, Photocatlytic Purification and Treatment of Water and Air, $1^{\text {st }}$ Ed., (Elsevier, Amsterdam, 1993), 152.

2. J. M. Herrmann, J. Diedier, P. Pichat, S. Malato, J. Blanco, $\mathrm{TiO}_{2}$-based solar photocatalytic detoxification of water containing organic pollutants. Case studies of 2,4-dichlorophenoxyaceticacid (2,4-D) and of benzofuran, Appl. Catal. B: Environ. 17 (1998) 15.

3. A. Fujishima, T. N. Rao, D. A. Tryk, Titanium dioxide photocatalysis, J. Photochem. Photobiol C. Photochem. Rev. 1 (1999) 1.

4. M. A. Fox, M. T. Dulay, Heterogeneous photocatalysis, Chem. Rev. 93 (1993) 341.

5. J. Bandara, J. A. Mielczarski, J. Kiwi, , Sensitized degradation of chlorophenols on iron oxides induced by visible light, Appl. Catal. B: Environ. 34 ( 2001) 321.

6. A. Hagfeldt, M. Gratzel, , Light-Induced Redox reactions in nanocrystalline systems, Chem. Rev. 95 (1995) 49.

7. F. Vogel, P. Poho, H. Weller, Sensitization of highly porous, polycrystalline $\mathrm{TiO}_{2}$ electrodes by quantum sized CdS Chem. Phys. Lett. 174 (1990) 241.

8. J. Bandara, K. Tennakone, Interparticle charge transfer in dye-sensitized films composed of two kinds of semiconductor crystallites, J. Colloid and Interface Science 236 (2001) 375.

9. V. Subramanian, E. E. Wolf, P. V. Kamat, Influence of metal/metal Ion concentration on the photocatalytic activity of $\mathrm{TiO}_{2}$-Au composite nanoparticles, Langmuir 19 (2003) 469.

10. J. Bandara, K. Tennakone, P. P. B. Jayatilaka, Composite tin and zinc oxide nanocrystalline particles for enhanced charge separation in sensitized degradation of dyes, Chemosphere 49 (2002) 439.

11. Z.-S., Wang, C. -H. Huang, Y. -Y. Huang, Y.-J. Hou, P. -H. Xie, B. -W. Zhang, B.-W., Cheng, H.-M., .A highly efficient solar sell made from a dye-modified $\mathrm{ZnO}$-covered $\mathrm{TiO}_{2}$ nanoporous electrode, Chem. Mater. 13 (2001) 678.

12. J. Bandara, C. C. Hadapangoda, W. G. Jayasekera, $\mathrm{TiO}_{2} / \mathrm{MgO}$ composite photocatalyst: The role of $\mathrm{MgO}$ in photoinduced charge carrier separation, Appl. Catal. B. Environment 50 (2004) 83.

13. J. Bandara, S. S. Kuruppu and U.W. Pradeep, The promoting effect of MgO layer in sensitized photodegradation of colorants on $\mathrm{TiO}_{2} / \mathrm{MgO}$ composite oxide, Colloids and Surfaces A: Physicochemical and Engineering Aspects 276 (2006) 197.

14. A. Kay, M. Gratzel, Dye-sensitized core-shell nanocrystals: Improved efficiency of mesoporous tin xxide electrodes coated with a thin layer of an insulating oxide, Chem Mater. 14 (2002) 2930.

15. K. Tennakone, J. Bandara, P.K.M. Bandaranayake, G.R.R. Kumara, Enhanced efficiency of a dye-sensitized solar cell made from MgO-coated nanocrystalline $\mathrm{SnO}_{2,}$ A. Konno, Jpn. J. Appl. Phys. 40 (2001) L732.

16. E. Palomares, J.N. Clifford, S.A. Haque, T. Lutz, J. R. Durrant, Control of charge recombination dynamics in dye sensitized solar cells by the use of conformally deposited metal oxide blocking layers, J. Amer. Chem. Soc. 125 (2003) 475.

17. A. J. Bard, L. R. Faulkner, Electrochemical Methods, $1^{\text {st }}$ Ed., (John Wiley and Sons, New York, 1980), 636. 
18. M. McCann, J. Pezy, Measurement of the flatband potentials of n-type and p-type semiconducots by rectified alternating photocurrent voltammetry, J. Electrochem. Soc., 128 (1981) 1735.

19. K. S. V. Santhanm, M. Sharon, Photoelectochemical Solar Cells, (Elsevier, Amsterdam, 1988), 162.

20. H. S. Jung, J. K. Lee, M. Nastasi, J. R. Kim, S. W. Lee, J. Y. Kim, J. S. Park, K. S. Hong, H. Shin, , Enhancing photocatalytic activity by using $\mathrm{TiO}_{2}$-MgO core-shell-structured nanoparticles, Appl. Phys. Lett. 88 (2006) 013107. 